\title{
Identification and Functional Analysis of Type III Effector Proteins in Mesorhizobium loti
}

\author{
Shin Okazaki, ${ }^{1}$ Saori Okabe, ${ }^{1}$ Miku Higashi, ${ }^{1}$ Yoshikazu Shimoda, ${ }^{2}$ Shusei Sato, ${ }^{2}$ Satoshi Tabata, ${ }^{2}$ \\ Masatsugu Hashiguchi, ${ }^{3}$ Ryo Akashi, ${ }^{3}$ Michael Göttfert, ${ }^{4}$ and Kazuhiko Saeki ${ }^{1}$ \\ ${ }^{1}$ Department of Biological Sciences, Faculty of Science, Nara Women's University, Nara 630-8506, Japan; ${ }^{2}$ Kazusa DNA \\ Research Institute, 2-6-7 Kazusa-kamatari, Kisarazu, Chiba 292-0818, Japan; ${ }^{3}$ Frontier Science Research Center, \\ University of Miyazaki, 1-1, Gakuen Kibanadai-nishi, Miyazaki-shi, 889-2192, Japan; ${ }^{4}$ Institute of Genetics, Dresden \\ University of Technology, Helmholtzstraße 10, 01069 Dresden, Germany
}

Submitted 9 April 2009. Accepted 21 September 2009.

\begin{abstract}
Mesorhizobium loti MAFF303099, a microsymbiont of the model legume Lotus japonicus, possesses a cluster of genes (tts) that encode a type III secretion system (T3SS). In the presence of heterologous nodD from Rhizobium leguminosarum and a flavonoid naringenin, we observed elevated expression of the $t$ ts genes and secretion of several proteins into the culture medium. Inoculation experiments with wild-type and T3SS mutant strains revealed that the presence of the T3SS affected nodulation at a species level within the Lotus genus either positively (L. corniculatus subsp. frondosus and L. filicaulis) or negatively (L. halophilus and two other species). By inoculating L. halophilus with mutants of various type III effector candidate genes, we identified open reading frame mlr6361 as a major determinant of the nodulation restriction observed for $L$. halophilus. The predicted gene product of mlr6361 is a protein of 3,056 amino acids containing 15 repetitions of a sequence motif of 40 to 45 residues and a shikimate kinase-like domain at its carboxyl terminus. Homologues with similar repeat sequences are present in the hypersensitive-response and pathogenicity regions of several plant pathogens, including strains of Pseudomonas syringae, Ralstonia solanacearum, and Xanthomonas species. These results suggest that $L$. halophilus recognizes Mlr6361 as potentially pathogen derived and subsequently halts the infection process.
\end{abstract}

Type III secretion systems (T3SSs) are essential for the pathogenicity of many animal- and plant-pathogenic bacteria. Bacteria use the T3SS to deliver effector proteins directly into eukaryotic cells or the external environment, where they manipulate host cellular processes to promote pathogenicity (Grant et al. 2006; Block et al. 2008). Phytopathogenic bacteria often use their effector proteins to suppress host immune responses that are activated by so-called pathogen-associated molecular patterns (PAMPs) (Jones and Dangl 2006). To counteract these threats, host plants have evolved to produce resistance (R) proteins which recognize the incoming effector proteins and allow them to induce resistant responses, including the hypersensitive response (HR) that halts pathogen invasion and disease (Abramovitch et al. 2006; Chisholm et al. 2006).

Corresponding author: K. Saeki; Telephone and Fax: +81-742-20-3028; Email: ksaeki@cc.nara-wu.ac.jp

* The $\boldsymbol{e}$-Xtra logo stands for "electronic extra" and indicates that a supplementary figure is published online.
The genes encoding T3SSs have also been identified in some rhizobia such as Rhizobium sp. strain NGR234 (Freiberg et al. 1997), Sinorhizobium fredii USDA257 (Krishnan et al. 2003), S. fredii HH103 (Marie et al. 2001; de Lyra et al. 2006), Bradyrhizobium japonicum USDA110 (Krause et al. 2002), and Mesorhizobium loti MAFF303099 (Kaneko et al. 2000). In contrast, S. meliloti 1021 (Galibert et al. 2001), Rhizobium leguminosarum bv. viciae 3841 (Young et al. 2006), and $M$. loti R7A (Sullivan et al. 2002) do not possess T3SS genes. The gene clusters for the T3SS (tts) in rhizobia consist of genes encoding structural core components of the T3SS apparatus, secreted proteins, and a transcriptional activator TtsI that induces the expression of other tts genes by binding to cis elements termed $t$ ts boxes (Krause et al. 2002; Wassem et al. 2008; Zehner et al. 2008). A nod box is located upstream of every rhizobial ttsI gene investigated to date. In the presence of compatible flavonoids released from legume roots, activated NodD binds nod boxes and activates the expression of nodulation (nod) genes. Hence, expression of ttsI is controlled by the same regulatory mechanism that controls the biosynthesis of Nod factors, which initiate nodule organogenesis in host legumes (Krause et al. 2002; Marie et al. 2004).

The T3SS can positively or negatively affect symbiosis depending on the host plant. In B. japonicum, deletion of tts genes causes a reduction in nodule number on Macroptilium atropurpureum (Siratro) and delayed nodulation with Glycine $\max$ (soybean) (Krause et al. 2002). In S. fredii USDA257, the T3SS prevents the soybean cv. McCall from being infected (Meinhardt et al. 1993; Bellato et al. 1997). Inactivation of the T3SS affects the ability of Rhizobium sp. strain NGR234 to nodulate a variety of tropical legumes (Viprey et al. 1998). The host-dependent symbiotic phenotypes could be caused by the type III effector proteins injected into the host cells. Secreted proteins of rhizobia are designated nodulation outer proteins (Nops) (Marie et al. 2001). The Nops of Rhizobium sp. strain NGR234 are either components of the T3SS-dependent pilus (NopA and NopB), the putative translocon that forms pores in the plant plasma membrane (NopX), or type III effectors (NopL, NopP, NopJ, NopM, and NopT), which are secreted via the T3SS (Viprey et al. 1998; Ausmees et al. 2004; Marie et al. 2004; Deakin et al. 2005; Saad et al. 2005; Skorpil et al. 2005; Dai et al. 2008; Kambara et al. 2009).

Mesorhizobium loti is the general name for the microsymbionts of Lotus spp. that include the model legume Lotus japonicus. Only a few strains, including MAFF303099, had been originally isolated from L. japonicus (Saeki and Kouchi 2000). The $M$. loti MAFF303099 genome contains the $t t s$ gene cluster, 
which encodes structural core components of the T3SS apparatus, T3SS-dependent pilus, and TtsI, which is highly similar to those of other rhizobia such as Rhizobium sp. strain NGR234 and B. japonicum USDA110 (Kaneko et al. 2002). Interestingly, $M$. loti R7A lacks the corresponding genes but contains genes not present in MAFF303099 that encode the type IV secretion system (T4SS). Hubber and associates (2004) reported that both R7A T4SS mutants and a MAFF303099 T3SS mutant nodulated Leucaena leucocephala, unlike the wild-type strains. These same mutant phenotypes with L. leucocephala suggest that the T3SS of MAFF303099 and the T4SS of R7A play an analogous role in the establishment of the symbiosis. The MAFF303099 genome does not encode the effector proteins identified in NGR234 such as NopL, NopP, NopJ, NopM, and NopT. Instead, MAFF303099 possesses Mlr6316, a member of the C48 family of cysteine proteases. Mutation of mlr6316 resulted in the formation of a small number of nodules on a small proportion of L. leucocephala plants, unlike the T3SS structural mutant that effectively nodulated on all inoculated plants (Hubber et al. 2004). Thus, MAFF303099 might secrete other effector proteins that affect the interaction with L. leucocephala and other host plants.

In this study, we characterized the T3SS of $M$. loti MAFF303099 by transcriptional and extracellular protein analyses. We also screened several Lotus spp. and identified some that exhibited T3SS-dependent symbiotic phenotypes. Using one of these host plants, Lotus halophilus, we identified a novel type III effector protein, Mlr6361, that negatively affects the symbiotic interaction.

\section{RESULTS}

\section{Genetic organization and transcriptional regulation} of the type III secretion system in M. loti MAFF303099.

The genes that encode the T3SS in M. loti MAFF303099 are clustered within a 25-kb region of the symbiosis island (Fig. 1). This region contains the genes that are conserved in all described tts gene clusters of other rhizobia; therefore, we assume that this region encodes all the essential proteins of the secretion machinery. The $t t s$ gene cluster includes $t t s I$, Rhizobium-conserved (rhc) genes, and nop genes that encode puta- tive secreted proteins. Open reading frames (ORF) encoding putative secreted proteins in the region were nopA, nopB, nop $C$, and nopX. Other known nops, such as nopL, nopM, nopP, nopJ, and nopT, were not found in M. loti.

A nod box consensus sequence was identified 315 bp upstream of $t$ tsI. Seven $t t s$ box motifs were found in the $t t s$ region (Figs. 1 and 2). To analyze the expression of the $t t s$ genes, translational fusions of lacZ with ttsI and nopX were constructed and integrated into the chromosome of $M$. loti strains to yield ML033 and ML031, respectively. To these strains, we subsequently transferred the plasmid pMP2112, which harbors nodD from $R$. leguminosarum, (López-Lara et al. 1995) and which had been proven to induce Nod factor synthesis by addition of the flavonoid naringenin in MAFF303099 (Niwa et al. 2001). $\beta$-Galactosidase activity in ML033 (pMP2112) increased approximately 13-fold after application of naringenin (Table 1). Similarly, $\beta$-galactosidase activity in ML031 (pMP2112) increased approximately eightfold in the presence of naringenin; however, elevated $\beta$-galactosidase activity was not observed in response to naringenin in the mutant ML037 which lacks ttsI. These results suggested that the $t t s$ gene cluster in $M$. lot i is

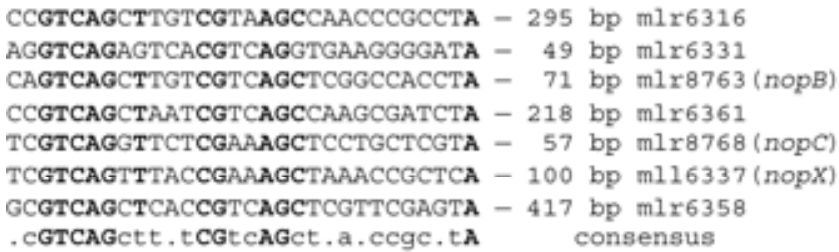

tcGTCAGctt, tcGaaAGct, ,gcc,c,ta Rhizobium sp. NGR234 tcGTCAGctT.tcGaaAGct...cc.cctA B. japonicum USDA110

Fig. 2. tts Box sequences identified in the Mesorhizobium loti MAFF303099. Nucleotides conserved in all cases are shown in bold uppercase letters. Numbers indicate the distance in base pairs between the tts box and the potential translational start site of the corresponding gene. In the consensus sequence, capital letters are used for invariant nucleotides and lowercase letters are used for nucleotides conserved in at least $50 \%$ of the sequences. Consensus sequences from Rhizobium sp. strain NGR234 (Marie et al. 2004) and Bradyrhizobium japonicum USDA110 (Krause A et al. 2002) are also shown.
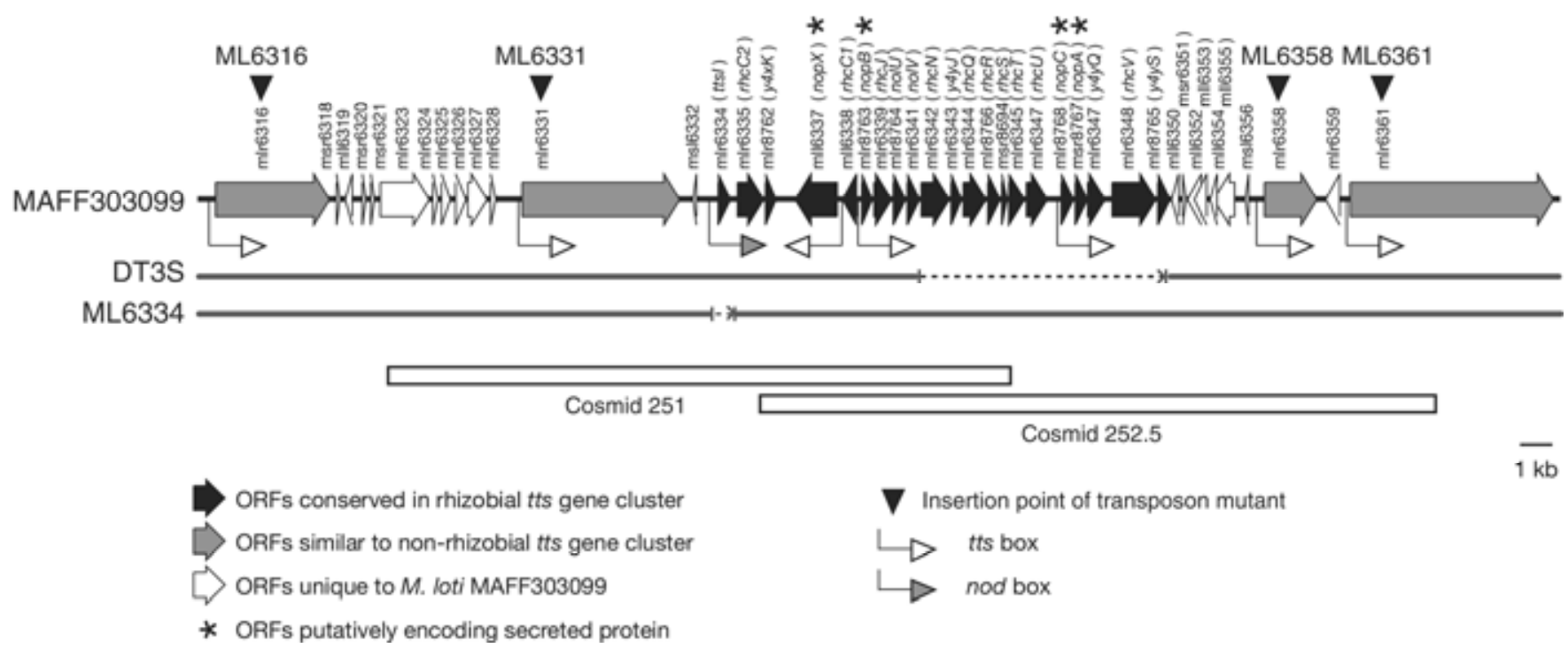

Fig. 1. Genetic organization of the tts genes of Mesorhizobium loti MAFF303099. The 47.4-kbp chromosomal region encompassing the RhizoBase genome coordinates 5138800 and 5186200 is shown. Orientations and sizes of the predicted open reading frames (ORF) are indicated. Gene designations of similar sequences in Rhizobium sp. strain NGR234 are given above the ORF. Deletions in mutants DT3S and ML6334 are indicated by broken lines. The direction of the arrows shows the orientation of the inserted kanamycin-resistant cassette. The position of the nod-box upstream of ttsI is shown by a gray arrowhead and the putative $t t s$ boxes are shown by unfilled arrowheads. 
regulated by NodD, plant-derived flavonoid inducer, and TtsI, as reported in other rhizobia (Krause A et al. 2002, Marie et al. 2004).

\section{Identification of the proteins secreted by the T3SS.}

Extracellular proteins from naringenin-induced and uninduced cultures of the wild-type MAFF303099 and type III mutant DT3S containing pMP2112 were partially purified and analyzed by sodium dodecyl sulfate polyacrylamide gel electrophoresis (SDS-PAGE). Several protein bands were only detected in the induced MAFF303099 cultures (Fig. 3). The molecular weights of these proteins were estimated at approximately $70,40,36,25,23,19,15$, and $7 \mathrm{kDa}$. These proteins were not detected in cultures of the type III mutant DT3S (pMP2112) in either the presence or absence of naringenin (Fig. 3).

The proteins from these bands were excised from the gel and analyzed by mass spectrometry. Significant data were obtained for two proteins of approximately 70 and $15 \mathrm{kDa}$ (Fig.
3 , asterisks). The obtained data indicated that the trypsin peptides derived from the band at $70 \mathrm{kDa}$ matched the internal sequences of Mll6337 of M. loti MAFF303099, which showed $72 \%$ identity with NopX (formerly NolX) of both Rhizobium sp. strain NGR234 (NP444155) and $S$. fredii $\mathrm{HH} 103$ (AAB17674) (Table 2). Similarly, the peptides derived from the band at $15 \mathrm{kDa}$ matched to the internal sequences of Mlr8763 of M. loti MAFF303099, which showed 63\% identity with NopB (formerly NolB) of both Rhizobium sp. strain NGR234 (NP444157) and $S$. fredii USDA257 (P33208) and $42 \%$ identity with NopB (B1r1812) of B. japonicum USDA 110 (NP 768452). These results suggested that $M$. loti MAFF303099 encodes a functional T3SS that secretes proteins, including known type III-secreted proteins.

\section{Symbiotic phenotypes of T3SS mutants on Lotus plants.}

In order to explore the significance of the M. loti T3SS, we compared symbiotic phenotypes of wild-type and T3SS mutants on several Lotus spp. We constructed a deletion mutant,

Table 1. Transcriptional activation of ttsI and nopX in Mesorhizobium loti

\begin{tabular}{|c|c|c|c|c|}
\hline \multirow[b]{2}{*}{ Strain } & \multirow[b]{2}{*}{ Genotype } & \multirow[b]{2}{*}{ Plasmid pMP2112 } & \multicolumn{2}{|c|}{$\beta$-Galactosidase activity ${ }^{\mathbf{a}}$} \\
\hline & & & Naringenin $+^{b}$ & - \\
\hline ML031 & nорX::lacZ & - & $32.9 \pm 12.5$ & $31.2 \pm 5.3$ \\
\hline ML031 & nopX::lacZ & + & $507.9 \pm 84.5$ & $63.2 \pm 7.9$ \\
\hline ML033 & ttsI::lacZ & + & $494.9 \pm 83.8$ & $36.6 \pm 9.2$ \\
\hline ML037 & nopX::lacZ, $\Delta t t s I$ & + & $42.2 \pm 11.0$ & $29.3 \pm 10.5$ \\
\hline
\end{tabular}

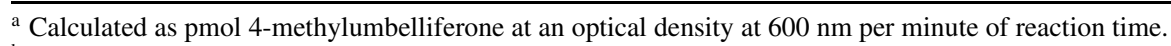

${ }^{\mathrm{b}}$ Naringenin was added at $1 \mu \mathrm{M}$.

A) $12 \%$ Tris-glycin SDS-PAGE

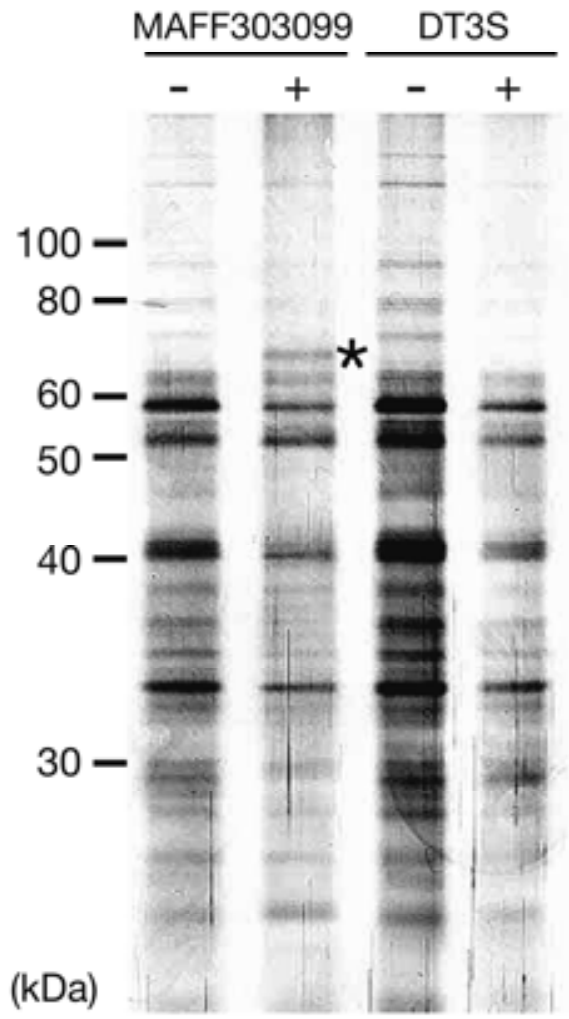

B) $15 \%$ Tris-trycine SDS-PAGE

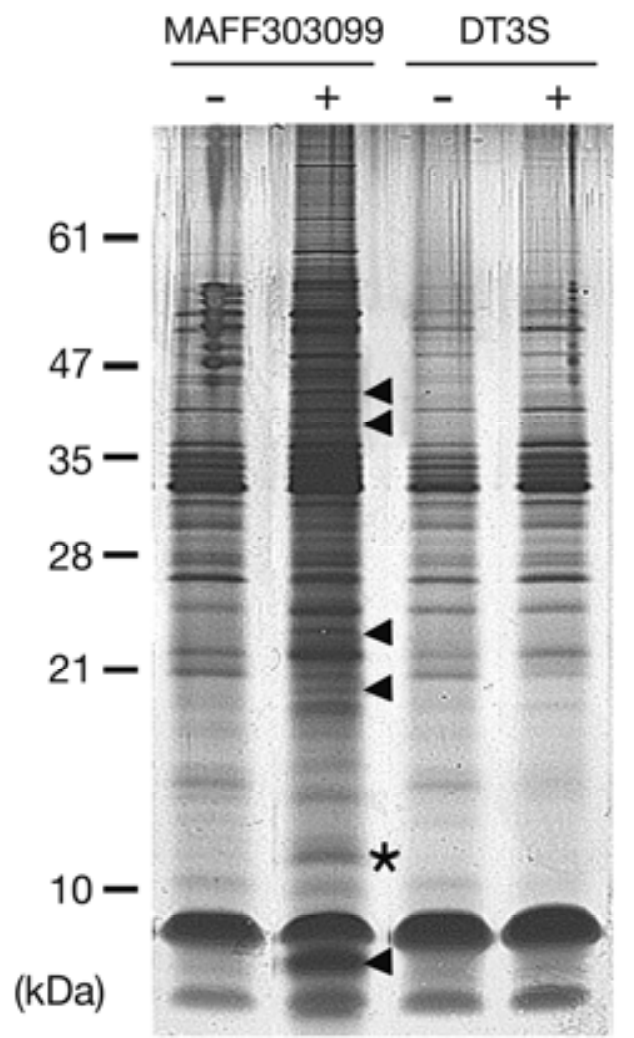

Fig. 3. Secreted proteins that are dependent on the type III secretion system (T3SS) in Mesorhizobium loti MAFF303099. MAFF303099 and DT3S harboring pMP2112 were cultured in the absence (-) or presence $(+)$ of $1 \mu \mathrm{M}$ naringenin. Extracellular proteins were concentrated and loaded onto A, 12\% Trisglycine sodium dodecyl sulfate polyacrylamide gel electrophoresis (SDS-PAGE) or B, 15\% Tris-tricine SDS-PAGE. The molecular weights of protein standards are indicated vertically. Arrowheads and asterisks indicate protein bands that were only visible in the induced culture of MAFF303099 (pMP2112). Asterisks indicate protein bands subjected to mass spectrometry analysis. 
DT3S, which lacked an 11-kbp region of the chromosome spanning the $M$. loti MAFF303099 genome coordinates $5,157,472$ to $5,168,624$, removing 12 conserved genes encoding both structural components of the T3SS and putative secreted proteins (Fig. 1). In the first screening, we identified six species that exhibited discernable differences in nodule number between the wild-type MAFF303099 and type III mutant DT3S. Depending on the species, the presence of the T3SS affected nodulation either positively ( $L$. corniculatus subsp. frondosus and L. filicaulis) or negatively (L. halophilus, $L$. peregrinus var. carmeli, and L. subbiflorus) (Fig. 4). We did not observe any significant difference in nodule number for $L$. japonicus Gifu B-129, although the rate of root elongation increased significantly in response to inoculation of DT3S compared with MAFF303099 (data not shown).

We further analyzed the symbiotic phenotypes of $L$. corniculatus subsp. frondosus and L. halophilus by inoculating them with the ttsI mutant ML6334 and DT3S harboring the cosmid 252.5, which complements the deleted chromosomal region (Fig. 1). On L. corniculatus subsp. frondosus, the wildtype strain induced more nodules than DT3S (Fig. 4). The phenotype of strain DT3S was partially restored by complementation with cosmid 252.5. Inoculation with ML6334 ( $\Delta t t s I)$ resulted in reduction of nodule numbers to levels similar to those observed for DT3S. Plant growth appeared to be correlated with nodule number (Fig. 5A). Plants were harvested at 45 days after inoculation and fresh weights were determined from at least eight plants per treatment. Plant fresh weights (average \pm standard deviation) were as follows: $521 \pm 91.6 \mathrm{mg}$ with MAFF303099, 303.2 $\pm 52.8 \mathrm{mg}$ with DT3S, $576.9 \pm 120.6 \mathrm{mg}$ with DT3S (cosmid 252.5), and $322.8 \pm 52.7 \mathrm{mg}$ with ML6334. In contrast, the presence of T3SS negatively affected nodulation of L. halophilus (Fig. 4). This species formed very few nodules upon inoculation with the wild-type strain. DT3S and ML6334 induced more nodules than MAFF303099 and promoted plant growth (Fig. 5B).

\section{Identification of the effector proteins responsible for the symbiotic interaction.}

In Rhizobium sp. strain NGR234 and B. japonicum USDA110, most operons encoding type III-secreted proteins are preceded by a tts box motif (Marie et al. 2004; Süss et al. 2006). In the $M$. loti MAFF303099 genome, three of the seven tts box motifs were identified upstream of mlr6337 (nopX), mlr8763 (nopB), and mlr8768 (nopC); the products of these are considered components of type III secretion-associated pili, which are required for the injection of effector proteins into the plant cells (Saad et al. 2007). Therefore, we selected the other four ORF that were preceded by $t t s$ boxes (mlr6316, mlr6331, mlr6358, and mlr6361) as type III effector candidates. Transposon mutants of these ORF were isolated from the signature-tagged mutant library constructed by Shimoda and colleagues (2008). These mutants were inoculated onto $L$. corniculatus subsp. frondosus and L. halophilus, and the symbiotic phenotypes were compared with the wild-type strain. On L. corniculatus subsp. frondosus, we could not observe significant differences between wild-type and mutant strains (Fig. 4D). However, on L. halophilus, inoculation with ML6361 resulted in the formation of effective nodules, similar to those found following inoculation with DT3S (Figs. 4E and 5B). The plants inoculated with the other mutants were similar to those inoculated with the wild-type strain. These results indicated that the protein encoded by mlr6361 was responsible for the nodulation restriction by $L$. halophilus.

\section{Features of the M. loti type III effector protein Mlr6361.}

The predicted product of mlr6361 is a protein of 3,056 amino acids that contains regions similar to portions of Mlr6331 and to proteins encoded in the hypersensitiveresponse and pathogenicity ( $h r p$ ) regions found in a number of plant-pathogenic bacteria, including strains of Pseudomonas syringae, Ralstonia solanacearum, and Xanthomonas spp. A phylogenetic tree constructed by the neighbor-joining method using an alignment shown in Supplementary Figure 1 revealed that Mlr6361 and Mlr6331 share more similarity with the Ralstonia proteins than with the Pseudomonas and Xanthomonas proteins (Fig. 6).

Mlr6361 and homologues contain a conserved multidomain "PRK09169" with unknown function found in the conserved domain database. The multidomain corresponds to a large part, approximately residues 800 to 2,800, of Mlr6361. Although PRK09169 (or a portion of PRK09169) is found in a wide range of proteins, its function is unknown and most PRK09169-containing proteins are assigned as hypothetical proteins. The central region of Mlr6361 (residues 916 to 1,572 , corresponding to the amino-terminal portion of PRK09169) contains a repeated sequence domain. This repeat domain is composed of 15 repetitions of a sequence motif of 40 to 45 residues that are similar to one another (Fig. 7). Similar repeat domains are also present in Mlr6331 and in homologues located in plant-pathogenic bacteria. The number of repeats ranges from 12 (RSp1374; $R$. solanacearum GMI1000; with GenBank accession number NP_522933) to 26 (XCV4314; Xanthomonas campestris pv. vesicatoria 85-10; YP_366045).

Comparison of the amino acid sequence of the carboxylterminal region of Mlr6361 (residues 2,830 to 3,056) revealed that it was highly similar to shikimate kinase (SK) (EC 2.7.1.71). SK catalyzes the transfer of a phosphoryl group from ATP to shikimate to yield shikimate 3-phosphate. This reaction is the fifth step in the shikimate pathway, whose final product, chorismic acid, is an essential intermediate for the synthesis of aromatic compounds such as aromatic amino acids, folate, and

Table 2. Naringenin-induced secreted proteins in Mesorhizobium loti MAFF303099

\begin{tabular}{|c|c|c|c|c|c|}
\hline Band & $\begin{array}{c}\text { Estimated molecular } \\
\text { mass }(\mathrm{kDa})\end{array}$ & Proteins identified & MOWSE score ${ }^{\mathrm{a}}$ & $\begin{array}{c}\text { Molecular mass } \\
\text { (kDa) }\end{array}$ & Peptides matched $^{b}$ \\
\hline 1 & 70 & Mll6337 (NopX) & 348 & 68.1 & $\begin{array}{l}\text { KFFGSGVLTRD } \\
\text { KTALEEAAAAGIDLPISMAKS } \\
\text { KTHAPETAAEQDAVSDMMTGRA } \\
\text { KTHAPETAAEQDAVSDMMTGRA } \\
\text { KAAIEGLQQDPELFYAIGSQGDGRC } \\
\text { KQAASQLLSDHLLFGLLNNSITGYKT }\end{array}$ \\
\hline 2 & 15 & Mlr8763 (NopB) & 333 & 17.4 & $\begin{array}{l}\text { KGVSGITSSVNKL } \\
\text { RAATQMSPLGDRV } \\
\text { RVLQTISAMYPDRA } \\
\text { RAGSPSFSEQAQFERA }\end{array}$ \\
\hline
\end{tabular}

\footnotetext{
${ }^{\mathrm{a}}$ MOWSE $=$ Molecular weight search.

${ }^{\mathrm{b}}$ Oxidized methionine is underlined.
} 
ubiquinone. Sequence alignment with SK family members, including Mycobacterium tuberculosis SK (MtSK), of which crystal structures have been extensively investigated ( $\mathrm{Gu}$ et al. 2002; Gan et al. 2006), revealed that Mlr6361 possesses all the important residues for ATP-binding, in Walker's Aand B-motifs, and for shikimate-binding (Walker et al. 1982; Krell et al. 1998; Gu et al. 2002) (Fig. 7C). Residues equivalent to those proposed to function in a phosphoryl transfer reaction in MtSK (Hartmann et al 2006) are also located in Mlr6361; such residues include Lys15, Asp34, and Arg117 (in MtSK numbering).

\section{DISCUSSION}

In this article, we have described the molecular and genetic analyses of the T3SS in Mesorhizobium loti MAFF303099. As in other rhizobia, the expression of the $t t s$ genes and protein secretion in M. loti MAFF303099 was controlled by NodD activating the expression of $t t s I$ in the presence of a flavonoid inducer. The fact that expression of the T3SS is coupled to the expression of the nod genes ensures that T3SS expression occurs during the infection phase of the symbiotic interaction. It has been reported that NopX of $S$. fredii USDA257 localizes in
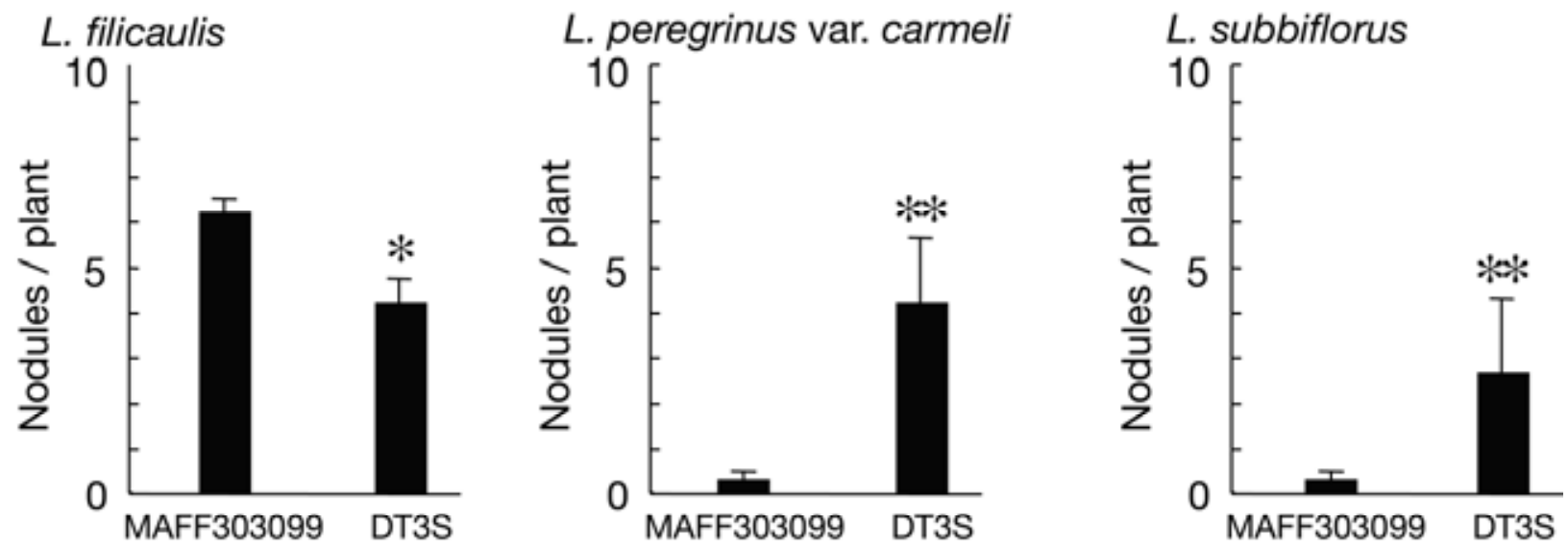

\section{L. coriniculatus subsp. frondosus}

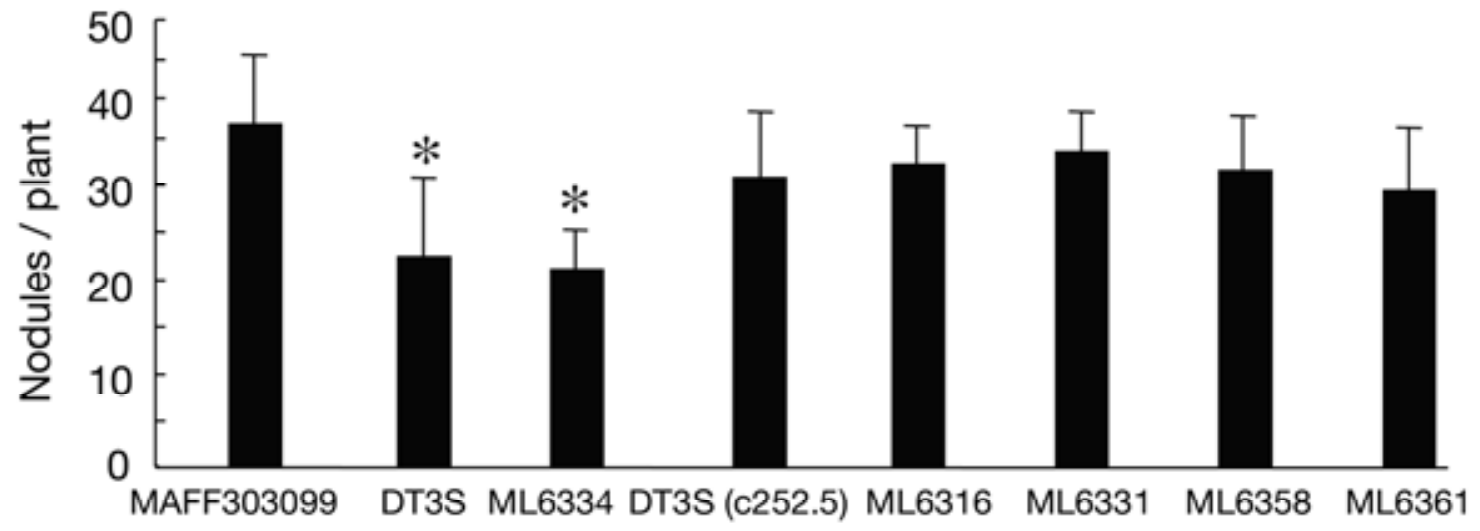

\section{L. halophilus}

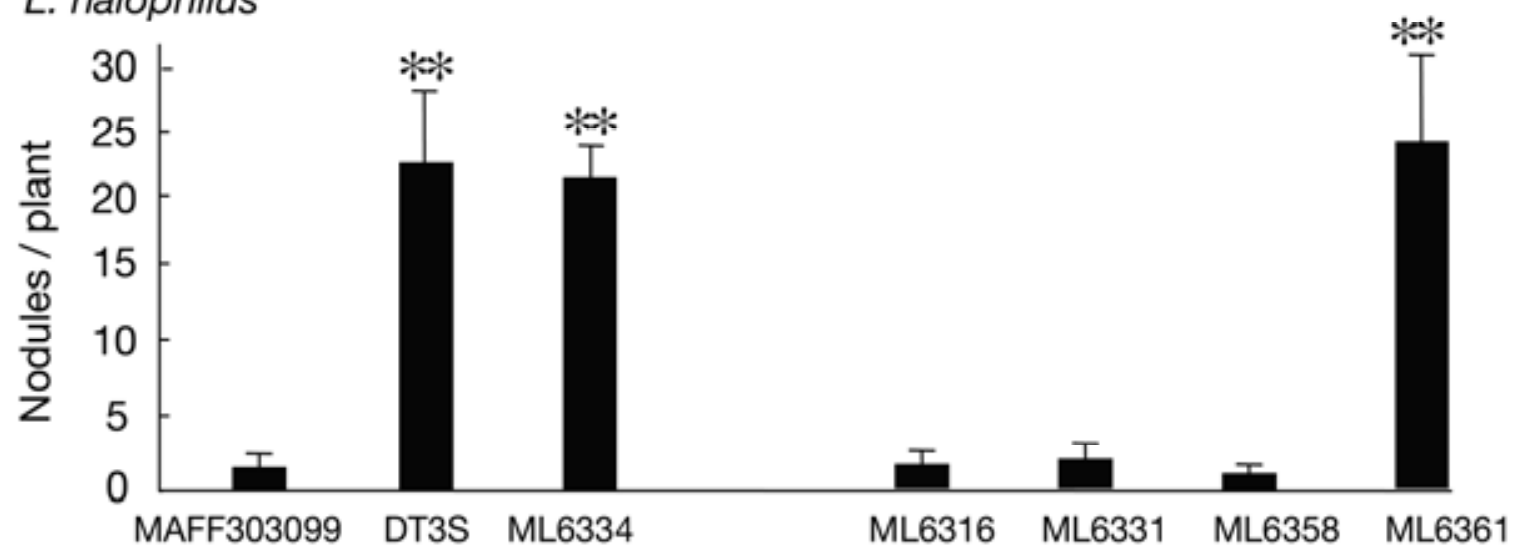

Fig. 4. Nodulation of Lotus spp. inoculated with wild-type and type III secretion mutants of Mesorhizobium loti MAFF303099. Nodule numbers were counted either 45 days (for Lotus corniculatus subsp. frondosus) or 35 days (the other species) after inoculation. Nodulation tests were performed at least three times, with 12 to 16 plants being tested each time. The values are means obtained from at least 24 plants and the error bars indicate standard deviations. Statistical analyses (Student's $t$ test) were performed comparing each mutant to the wild-type strain. A single asterisk represents $P<0.05$ and double asterisks represent $P<0.001$. 
soybean infection threads but not in mature nodules (Krishnan 2002). We also performed preliminary cytological analysis of the roots of L. japonicus inoculated with reporter strains ML031 and ML037 that have chromosomally integrated lacZ gene under the control of nopX promoter with authentic and disrupted $t t s I$ backgrounds, respectively. The coloration derived from $\beta$-galactosidase was observed within the infection thread only in the root inoculated with ML031 and not with ML037. In addition, as presented in this study, the abortion of the nodule formation on L. halophilus by the wild-type MAFF303099 also suggests that T3SS functions in the infection phase. Animal pathogens utilize T3SS to allow persistence within host cells (Schlumberger and Hardt 2006), while plant pathogens use it to suppress PAMP-triggered innate immunity of host plants (Zhou and Chai 2008). Taken together, it is likely that the rhizobial T3SS may facilitate release into the symbiosome or suppress host defense response in order to occupy its niche in the infection threads. Recently, Zehner and associates (2008) reported that B. japonicum T3SS are expressed in both early infection stages and mature nodules of M. atropurpureum. Therefore, it is possible that, in a certain combination of rhizobial species and host legumes, T3SS could also play a role in the later stage of symbiosis.

Our results indicate that Mlr6361 is responsible for the diminished symbiotic interaction with L. halophilus. The presence of Mlr6361 homologues has not been reported thus far in rhizobia but some plant pathogens, such as $P$. syringae, $R$. solanacearum, and Xanthomonas spp., possess similar genes in their $h r p$ region. To date, no evidence has been presented demonstrating that homologous gene products produced by plant

\section{A) Lotus corniculatus subsp. frondosus}

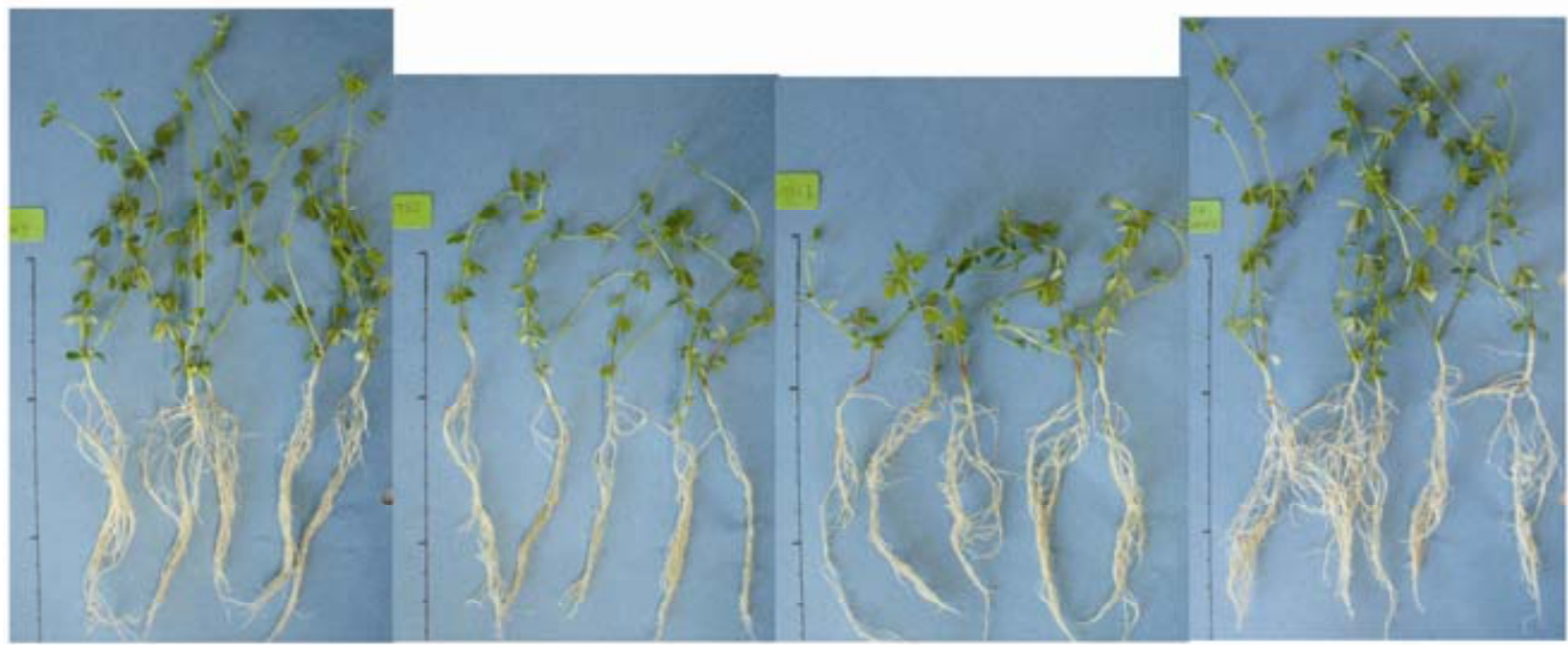

MAFF303099

DT3S

ML6334

DT3S (cosmid 252.5)

\section{B) Lotus halophilus}

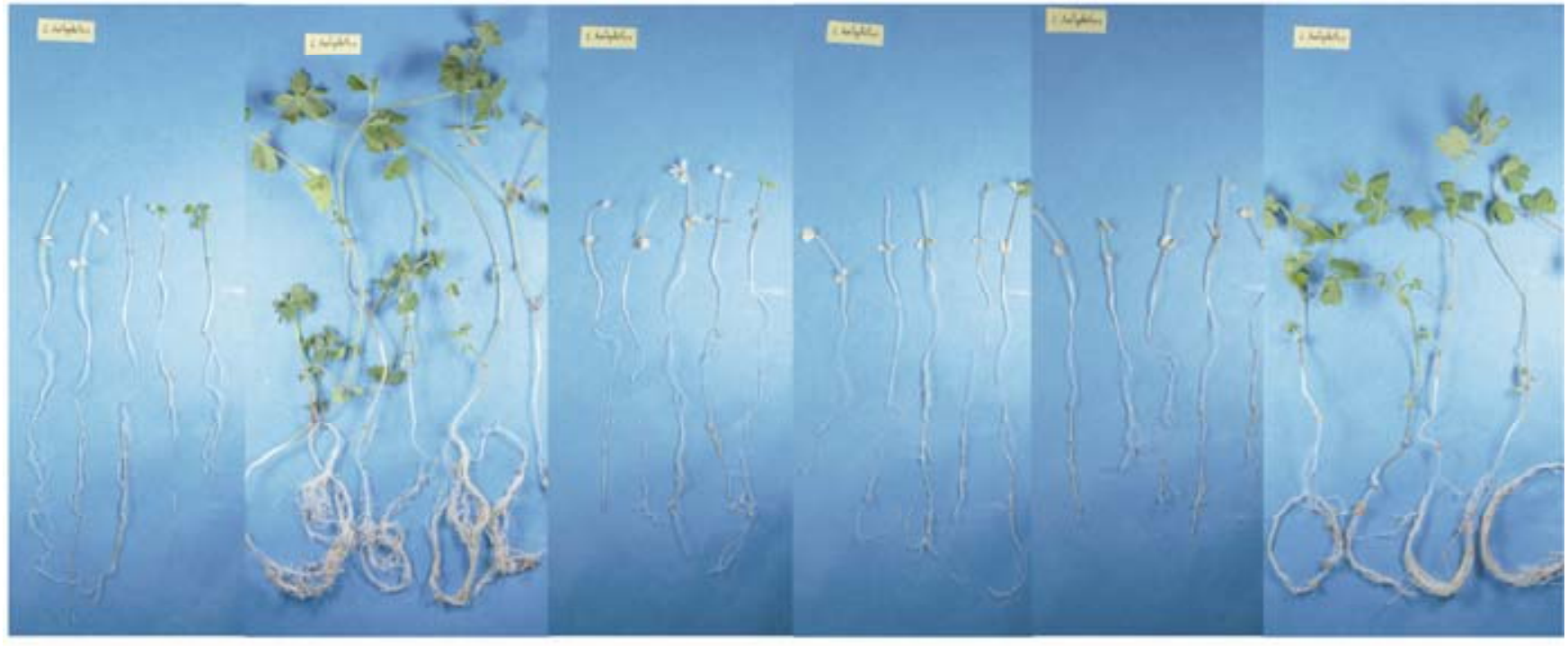

\section{MAFF303099 \\ DT3S \\ ML6316 \\ ML6331 \\ ML6358 \\ ML6361}

Fig. 5. Lotus spp. plants inoculated with the wild-type strain and tts mutants. A, Lotus corniculatus subsp. frondosus inoculated with various strains of Mesorhizobium loti, photographed 45 days after inoculation. B, L. halophilus inoculated with various strains of M. loti, photographed 35 days after inoculation. 
pathogens are secreted by T3SS or that they possess biological activity in association with host plants. Characteristic features of Mlr6361 include the conserved mutidomain PRK09169 with internal repeat domain and an SK-like domain at its carboxyl terminus. Any or some of these and still unidentified domain might play a role in the host cells, which leads to halting the infection process on L. halophilus, as discussed below.

An interesting feature of the conserved domain PRK09169 is the internal repeat sequences (Fig. 7) which is also found in the homologues of phytopathogenic bacteria. The high degree of conservation of the repeat region indicates its important role in defining the structure of the protein. Different types of repeat sequences are found in other type III effectors. Among them, leucine-rich repeats (LRR) are found in a number of type III effectors that are essential for the pathogenicity of animal and plant pathogens (Evdokimov et al. 2001; Haraga and Miller 2003; Zhu et al. 2008; Kambara et al. 2009). The LRR domain is supposed to be involved in protein-protein interactions (Kobe and Kajava 2001). Therefore, there is a possibility that the repeat domain within PRK09169 is involved in interaction with some protein to perturb host functions and recognized by particular hosts like $L$. halophilus to lead to a reaction to halt infection.

Another interesting feature of Mlr6361, the presence of an SK-like domain at its carboxy terminus, suggests that this protein may have an enzymatic function. The shikimate pathway is responsible for the biosynthesis of aromatic compounds in bacteria, yeast, fungi, and plants. In higher plants, the aromatic amino acids produced by this pathway further serve as precursors for various secondary metabolites, such as phenylpropanoids and flavonoids (Herrmann 1995), which have been reported to play important roles in plant defense systems (Dixon and Paiva 1995; Dixon and Steele 1999). Induction of expres- sion of SK genes by elicitor treatments has been reported in cultured rice cell and tomato cells (Görlach et al. 1995; Kasai et al. 2005). Taken together, there is an alternative possibility that Mlr6361 could act as shikimate kinase in plant cells to perturb host metabolisms to convert a favorable microenvironment for the infection process and that either such function or SK domain itself is recognized by L. halophilus to lead to aborted infection. In addition, it might be noted that the homologues of phytopathogenic bacteria do not possess the carboxyterminus SK domain, although some of them (PSPPH_A0133, RRSL_01097, RRSL_03921, and RRSL_04182) are annotated as shikimate kinases.

Despite the high homology with Mlr6361, Mlr6331 appeared to be unrelated to the nodulation restriction by L. halophilus. In addition to the possibility that a feature responsible for the nodulation restriction is present in Mlr6361 but not present in Mlr6331, there is another possibility, that Mlr6331 is not secreted by the T3SS due to an incompatible $\mathrm{N}$-terminal sequence. It has been reported that type III-secreted proteins of $P$. syringae exhibit common features at the N-terminal region: i) high serine percent in the first 50 amino acids, ii) an aliphatic amino acid (Ile, Val, or Leu) or Pro at the third or fourth position, and iii) the absence of negatively charged amino acid in the first 12 amino acids (Guttman et al. 2002; PetnickiOcwieja et al. 2002). Because the $\mathrm{N}$-terminal region of Mlr6331 conforms to the features less strictly than that of Mlr6361, it is possible that Mlr6331 is recognized as a lesscompatible substrate for T3SS machinery.

In the present study, we could not identify which effector protein of MAFF303099 is responsible for the nodulation enhancement on L. corniculatus subsp. frondosus. It has been reported that NopL and NopP of Rhizobium sp. strain NGR234 are major determinants for the positive effect on symbiosis

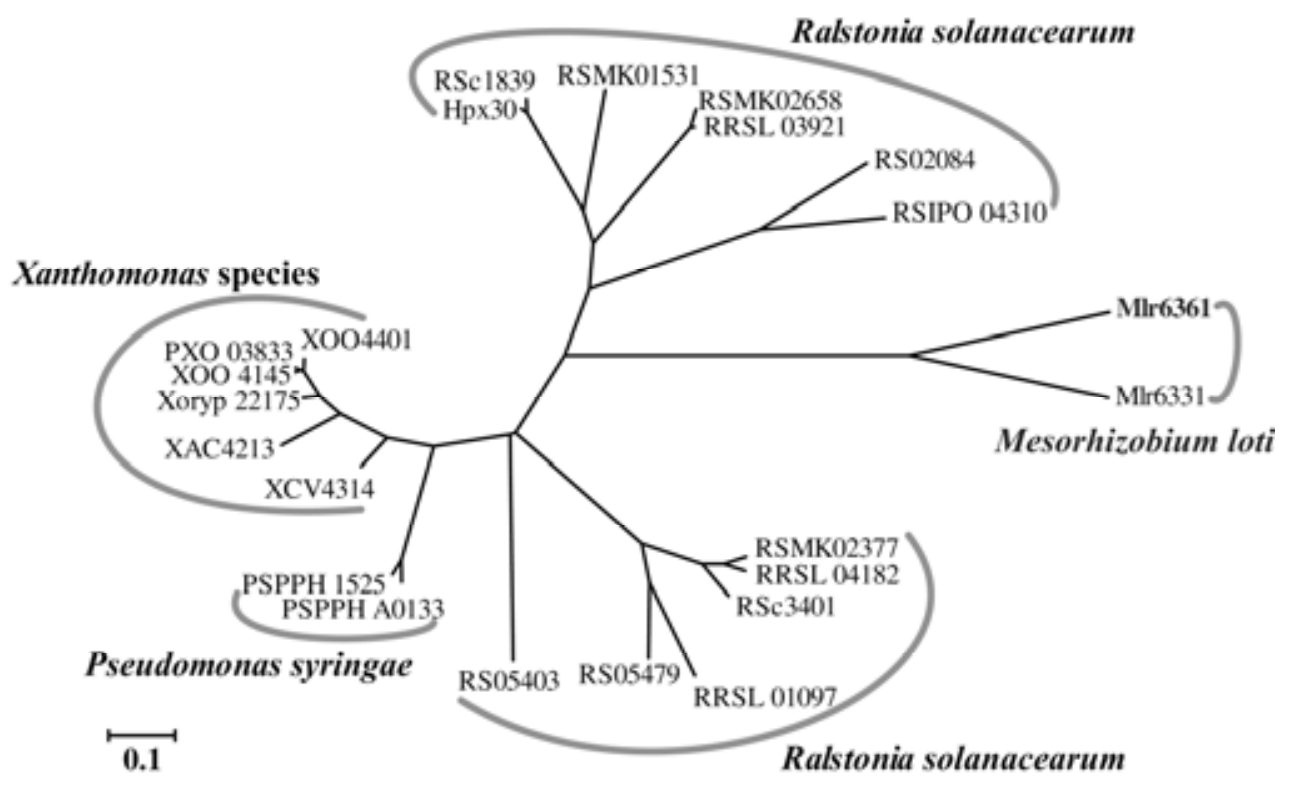

Fig. 6. Phylogenetic tree of Mlr6361 and its homologues. A phylogenetic tree was constructed by the neighbor-joining method with the MEGA 4.0 program using full-length amino acid sequence comparison shown in the supplementary figure. GenBank accession numbers are as follows: XOO4401 (Xanthomonas oryzae pv. oryzae KACC10331), YP_203040; Xoryp_22175 (X. oryzae pv. oryzicola BLS256), ZP_02245275; PXO_03833 (X. oryzae pv. oryzae PXO99A), YP_001911573; XOO_4145 (X. oryzae pv. oryzae MAFF311018), YP_453174; XCV4314 (X. campestris pv. vesicatoria str. 85-10), YP_366045; XAC4213 (X. axonopodis pv. citri str. 306), NP_644512; PSPPH_1525 (Pseudomonas syringae pv. phaseolicola 1448A), YP_273779; PSPPH_A0133 (P. syringae pv. phaseolicola 1448A), YP_272239; RS̄05403 (Ralstonia solanacearum GMI1000), NP_522491; RSIPO_04310 (R. solanacearum IPO1609), YP_002258003; RSp1374 (R. solanacearum GMI1000), NP_522933; RRSL_03921 (R. solanacearum UW551), ZP_00943380; RSMK02658 (R. solanacearum MolK2), YP_002254685; RSc1839 (R. solanacearum GMI1000), NP_519960; RSc1839 (R. solanacearum GMI1000), CAD15541; hpx30 (R. solanacearum RS1000), BAD42408; RSMK01531 (R. solanacearum MolK2), YP_002254417; Mlr6361 (Mesorhizobium loti MAFF303099), NP_106885; Mlr6331 (M. loti MAFF303099), NP_106855; RSp0296 (R. solanacearum GMI1000), NP_521857; RRSL_04182 (R. solanacearum UW551), ZP_00943200; RSMK02377 (R. solanacearum MolK2), YP_002252489; RSc3401 (R. solanacearum GMI1000), NP_521520; and RRSL_01097 (R. solanacearum UW551), ZP_00946113. The horizontal bar represents a distance of 0.1 substitutions per site. 
with tropical legumes Flemingia congesta and Tephrosia vogelii (Marie et al. 2003; Skorpil et al 2005). Both effectors were shown to be phosphorylated by plant kinases, and NopL could prevent full induction of pathogenesis-related defense proteins, including chitinase and $\beta$-1,3-glucanase, when expressed in plant cells (Bartsev et al. 2004). NopL and NopP are not encoded in the genome of MAFF303099. M. loti MAFF303099 secretes several proteins in a T3SS-dependent manner (Fig. 3).

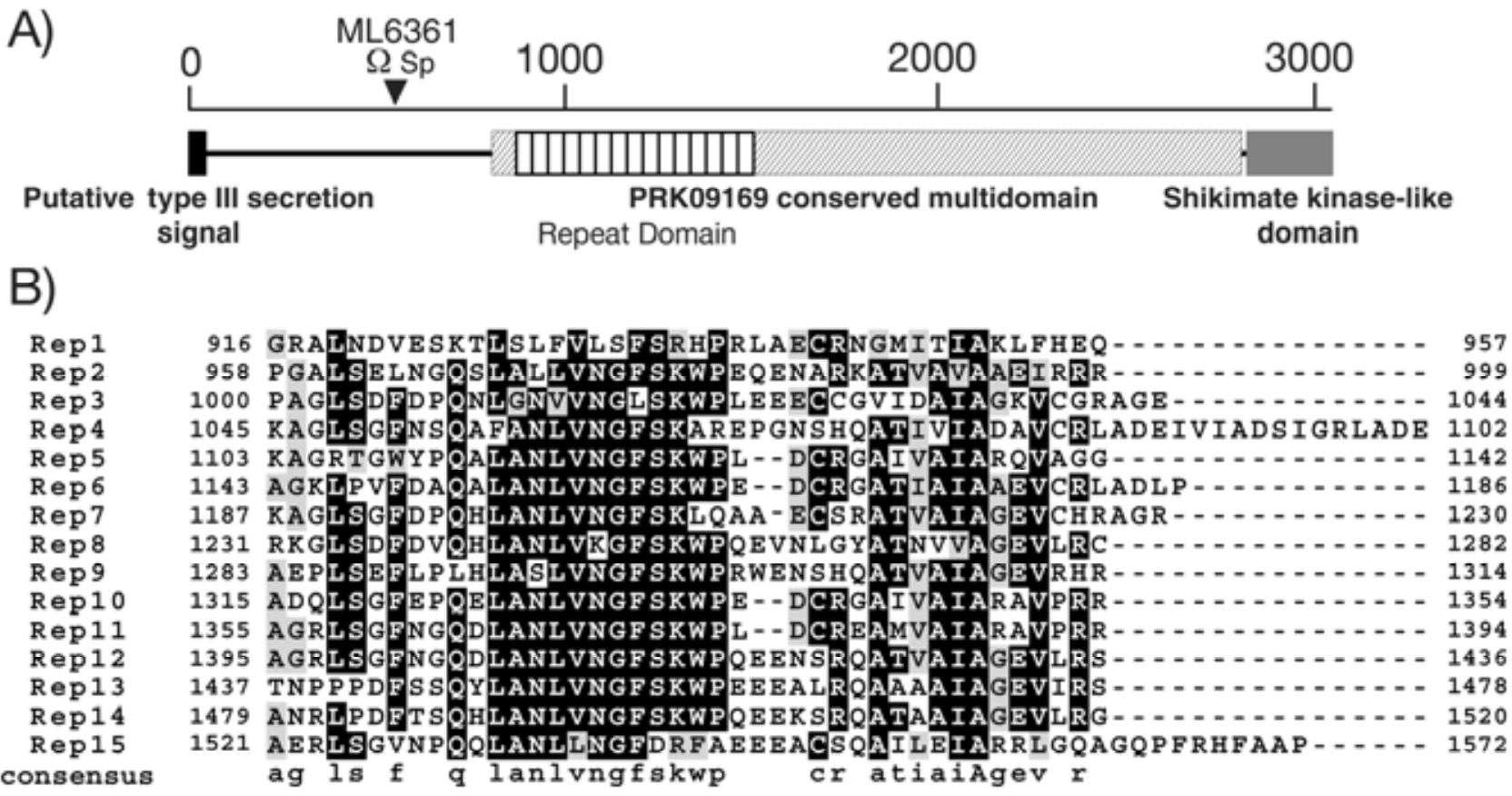

C)

M1r6361 M1r6331

M113573

MtSK

Os SR 1

$\operatorname{Ml} 6361$

M1r6331

M113573

Mtsk

OsSK 1

MIr6361

M1r6331

M113573

MtSK

OSSK 1
Walker A-motif ㄴ. 2830
2149
EAHADSTVGA L LRR LQVAP PRRTERSPIATEILGALGARSIVLVGVKGAGKSSLGRALA
1
1 shikimate-binding domain $\underset{t}{\longrightarrow}$ Walker B-motif 2887 KRLGLRFIDTD̂QEIQKQTGK-SITQIFNTNGEGYFRKLEAEAIARVLEQGPAVIATGGGS 2209 KRLGMRFVDSDRKI EAKTGK - SVAKIVAEDGEAYFRDLEVNEIRQ SLELGSAVLATGGEA 44 TMLSLPEIDSDQEI ESVSRM - TVPELFERYGEAEFRALEQRVILRVLENGPQVLSTGGGA 24 RALGVGLLDTDVAIEQRTGR - SIADIFATDGEQEFRR IEEDVVRAALADHDGVLSLGGGA 58 EVLGY SFFDSDKLVEQAVGMPSVAQIFKVH SEAFFRDNES SVLRDLSSMKRLVVATGGGA

$$
\stackrel{\text { LID domain }}{\star} \longrightarrow
$$

2946 LNDEQTRRLIADRAVSIWINTDPRVLRRRLR - - NDTTRPLLRGSDRD - - - - - - QTVPQLM

2268 FMIEEIRHYVGEKAVS IWLNT SEDVIRRNLR - - DNIRGPKVQTADQA - - - - - QTITDLM

103 FMNAQTREAIAGHGVSVWLKAELDLLMDRVS - - KKQNRPLLKSADPR - - - - - AVLERLM

83 VTSPGVRAALAGHTVVYLEISAAEGVRRTG - - - GNTVRPLLAGPDRA - - - - - EKYRALM

118 VIRP - VNWKYMKRGLSVWLDVPLDALARRI AKVGTASR PLLDQP SGDPYTMAF SKL SMLA

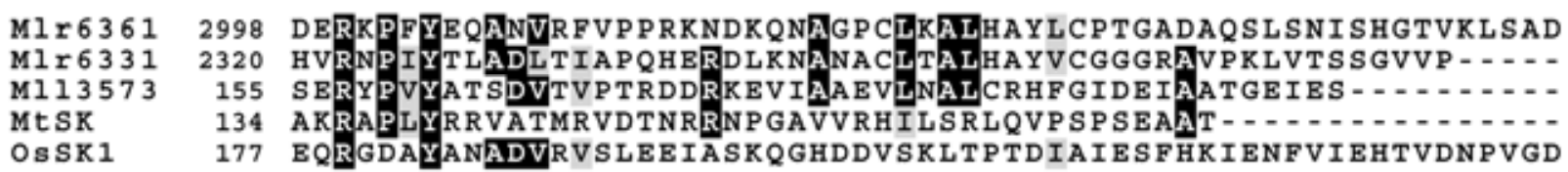

Fig. 7. Features of Mlr6361. A, Domain structure of Mlr6361. The three domains of Mlr6361 protein (3,056 amino acids) are illustrated: the N-terminal putative type III secretion signal (first 50 amino acids, filled box); PRK09169 conserved multidomain (residues 803 to 2,794, hatched), with the internal repeat domain (residues 916 to 1,572, vertically striped) consisting of 15 repetitions of a sequence motif of 40 to 45 amino acids; and the C-terminal shikimate kinase-like domain (residues 2,830 to 3,056, gray). The black triangle indicates the insertion point of $\Omega$ interposon in mutant ML6361. B, Amino acid sequence of the repetitive amino-acid region in the sequence of Mlr6361. The internal region of Mlr6361 (residues 916 to 1,572) is shown. Repeat segments were aligned with the CLUSTAL W algorithm. C, Multiple amino acid sequence alignments of a C-terminal shikimate kinase-like domain with other shikimate kinase proteins. The sequences shown include Mlr6361 (NP_106885, residues 2,830 to 3,056), Mlr6331 (NP_106855, residues 2,149 to 2,373), Ml13573 (NP_104650), MtSK (Mycobacterium tuberculosis CDC1551 shikimate kinase, AAK46924), and OsSK1 (Oryza sativa Japonica group shikimate kinase 1, BAD83412, residues 61 to 295). Walker A and B motifs (boxed) correspond to regions that resemble the functional motifs identified in other nucleotide-binding enzymes (Walker et al. 1982). Two-headed arrows indicate the putative shikimate-binding domain and the LID domain (Gu et al. 2002). Identical residues are in black and similar residues are in gray. Asterisks indicate the residues proposed to function in phosphoryl transfer reaction in MtSK: Lys15, Asp34, and Arg117 in MtSK numbering (Gu et al. 2002; Gan et al. 2006; Hartmann et al 2006). 
In the present study, we have identified two of these proteins. Further analysis of the unidentified secreted proteins could provide additional insights into the rhizobial type III effector and its role in legume-Rhizobium spp. symbiosis.

In conclusion, we have presented evidence that $M$. loti MAFF303099 has a functional T3SS that is involved in modulation of symbiotic performance with certain host Lotus spp. We also showed that the novel type III effector Mlr6361, which has homologues that are widely present in plant pathogens, is a major determinant of nodulation restriction by some host legumes. This is the first genetic evidence that a protein of this group has a biological effect in plant-microbe interactions.

\section{MATERIALS AND METHODS}

\section{Bacterial strains and growth conditions.}

The bacterial strains and plasmids used in this study are listed in Table 3. M. loti cultures were grown aerobically at $28^{\circ} \mathrm{C}$ in tryptone-yeast extract (TY) medium (Hattori et al. 2002) or Rhizobium-defined medium (RDM) (Ronson et al. 1987). Escherichia coli cells were grown at $37^{\circ} \mathrm{C}$ in Luria broth or Terrific broth (Sambrook and Russel 2001). Antibiotics were added to the medium at the following concentrations: for $M$. loti, phosphomycin at $100 \mu \mathrm{g} \mathrm{ml}^{-1}$, tetracycline at $10 \mu \mathrm{g} \mathrm{ml}^{-1}$, kanamy-

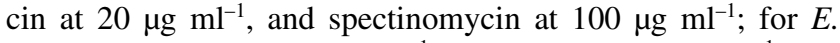
coli, tetracycline at $12.5 \mu \mathrm{g} \cdot \mathrm{ml}^{-1}$, ampicillin at $100 \mu \mathrm{g} \cdot \mathrm{ml}^{-1}$, and kanamycin at $50 \mu \mathrm{g} \cdot \mathrm{ml}^{-1}$.

\section{Construction of mutants.}

Mutants were constructed by a modification of the one-step method described by Datsenko and Wanner (2000) as described previously (Okazaki et al. 2007). Disruption of ttsI (mlr6334) was carried out as follows. The Flp recognition target (FRT)flanked kanamycin resistance gene (FRT-kan-FRT) was polymerase chain reaction (PCR) amplified using pKD13 (Datsenko and Wanner 2000) as the template and primers mlr6334U and mlr6334L, which contained 45-bp extensions homologous to regions flanking mlr6334 (Table 3). The resulting PCR products were electroporated into $E$. coli $\mathrm{DH} 10 \mathrm{~B}$ harboring both cosmid 251 and plasmid pKD46 and were integrated into the cosmid via Lambda Red-mediated recombination. The cosmid derivatives with deletion insertion loci were transferred to $M$. loti MAFF303099 by conjugation. The deletion mutant ML6334 was obtained as a result of homologous recombination facilitated by plasmid incompatibility using pKS808 as previously described (Hattori et al. 2002). DT3S, which carries an 11-kbp deletion in the tts gene cluster spanning 12 genes (mlr6342 to mlr8765) was similarly constructed; in this case,

Table 3. Bacterial strains, plasmids, and oligonucleotides used in this study

\begin{tabular}{|c|c|c|}
\hline $\begin{array}{l}\text { Strain, plasmid, or } \\
\text { oligonucleotide }\end{array}$ & Characteristics or sequence $^{a}$ & Reference or source \\
\hline \multicolumn{3}{|l|}{ Bacterial strains } \\
\hline \multicolumn{3}{|l|}{ Mesorhizobium loti } \\
\hline MAFF303099 & Wild-type stain; $\mathrm{Pm}^{\mathrm{r}}$ & $\begin{array}{l}\text { Saeki and Kouchi 2000; } \\
\text { Kaneko et al. } 2000\end{array}$ \\
\hline ML6334 & $\Delta$ mlr6334::kan derivative of MAFF303099; $\mathrm{Pm}^{\mathrm{r}}, \mathrm{Km}^{\mathrm{r}}$ & This study \\
\hline DT3S & $\begin{array}{l}\text { MAFF303099 derivative with genome deletion at positions } 5,157,472 \text { to } 5,168,624(\Delta \mathrm{mlr} 6342- \\
\text { mlr8765) and inserted } \mathrm{Km} \text { cassette; } \mathrm{Pm}^{\mathrm{r}}, \mathrm{Km}^{\mathrm{r}}\end{array}$ & This study \\
\hline ML031 & nopX $(\mathrm{mlr6337})::$ lacZ integrated into MAFF303099; $\mathrm{Pm}^{\mathrm{r}}, \mathrm{Tc}^{\mathrm{r}}$ & This study \\
\hline ML033 & ttsI (mlr6334): :lacZ integrated into MAFF303099; $\mathrm{Pm}^{\mathrm{r}}, \mathrm{Tc}^{\mathrm{r}}$ & This study \\
\hline ML037 & nopX $(\mathrm{mrl6337}): \because$ lacZ integrated into ML6334; $\mathrm{Pm}^{\mathrm{r}}, \mathrm{Km}^{\mathrm{r}}, \mathrm{Tc}^{\mathrm{r}}$ & This study \\
\hline ML6316 & $\begin{array}{l}\text { mlr6316:: } \Omega \text { transposon mutant of MAFF303099, 10T03a09 (Mini-Tn insertion at 2,595th nucleotide } \\
\text { in total 5247-bp ORF); } \mathrm{Pm}^{\mathrm{r}}, \mathrm{Sp}^{\mathrm{r}}\end{array}$ & Shimoda et al. 2008 \\
\hline ML6331 & $\begin{array}{l}\text { mlr6331:: } \Omega \text { transposon mutant of MAFF303099, 11T02g05 (Mini-Tn insertion at 766th nucleotide in } \\
\text { total 7122-bp ORF); } \mathrm{Pm}^{\mathrm{r}}, \mathrm{Sp}^{\mathrm{r}}\end{array}$ & Shimoda et al. 2008 \\
\hline ML6358 & $\begin{array}{l}\text { mlr6358:: } \Omega \text { transposon mutant of MAFF303099, 40T02g01 (Mini-Tn insertion at 962th nucleotide in } \\
\text { total 2439-bp ORF); } \mathrm{Pm}^{\mathrm{r}}, \mathrm{Sp}^{\mathrm{r}}\end{array}$ & Shimoda et al. 2008 \\
\hline ML6361 & $\begin{array}{l}\text { mlr6361:: } \Omega \text { transposon mutant of MAFF303099, 27T02d12 (Mini-Tn insertion at 1,605th nucleotide } \\
\text { in total 9171-bp ORF); } \mathrm{Pm}^{\mathrm{r}}, \mathrm{Sp}^{\mathrm{r}}\end{array}$ & Shimoda et al. 2008 \\
\hline \multicolumn{3}{|c|}{ 117 } \\
\hline DH10B & $\begin{array}{l}\mathrm{F}^{-}, \text {mcrA, } \Delta(\text { mrr-hsdRMS-mcrBC }), \varnothing 80 \mathrm{~d} l a c Z, \Delta \mathrm{M} 15, \Delta l a c X 74, \text { deoR, recA1, araD139, } \Delta(\text { ara } \\
\text { leu } 7697, \text { galU, galK, } \lambda^{-}, \text {rpsL, endA1, nup } G\end{array}$ & Invitrogen \\
\hline S17-1 & recA, pro, $h s d R$, RP4-2-Tc::Mu-Km::Tn & Simon et al. 1983 \\
\hline \multicolumn{3}{|c|}{ 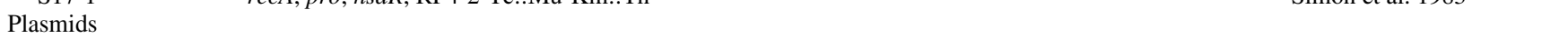 } \\
\hline cosmid 251 & Ordered cosmid of MAFF303099 containing genome region coordinates 5,133,286-5,161,587; $\mathrm{Tc}^{\mathrm{r}}$ & Hattori et al. \\
\hline cosmid 252.5 & Ordered cosmid of MAFF303099 containing genome region coordinates 5,150,567-5,180,946; $\mathrm{Tc}^{\mathrm{r}}$ & Hattori et al. \\
\hline pKD13 & oriR6K blaM, FRT-aphA-FRT; $\mathrm{Km}^{\mathrm{r}}$ & Datsenko and Wanner 2000 \\
\hline pKD46 & oriR101, repA101(Ts), blaM, araBp-gam-bet-exo; $\mathrm{Ap}^{\mathrm{r}}$ & Datsenko and Wanner 2000 \\
\hline pSUPlacZ481uidA & $\begin{array}{l}\text { Derivative of pSUP202 (Simon et al. 1983) used for translational fusions with lac } Z \text { and transcriptional } \\
\text { fusions with uidA, oriT of RP4, Tc }\end{array}$ & $\begin{array}{l}\text { S. Zehner and M. Göttfert, } \\
\text { unpublished }\end{array}$ \\
\hline \multicolumn{3}{|c|}{ (1) } \\
\hline mlr6334U & $\begin{array}{l}\text { 5'-CAGTCTCGGTGACCTGTCCTACCATTAATAGGAGATGAAATGCGAATTCCGGGGA } \\
\text { TCCGTCGACC-3' }\end{array}$ & This study \\
\hline mlr6334L & $\begin{array}{l}\text { 5'-TCGGCCAACTATACGAATGTCGCGCTAGTCACATTCAAGAATGTATGTAGGCTGG } \\
\text { AGCTGCTTCG-3' }\end{array}$ & This study \\
\hline mlr6342U & 5'-GCGTCTCGGCTTCGGGTCGCTTTCTGAAAAAGGCGAACTGTGACAATTCCGGGGAT & \\
\hline & CCGTCGACC-3' & This study \\
\hline mlr8765L & $\begin{array}{l}\text { 5'-AACGCACTCAGGTCCGGACTTCCTTTAAAACGCAAGCGACAGGTCTGTAGGCTGGA } \\
\text { GCTGCTTCG-3' }\end{array}$ & This study \\
\hline mlr6334for & 5'-AACCGACTAGTAGGACGACGGTTATC-3' & This study \\
\hline mlr6334rev & 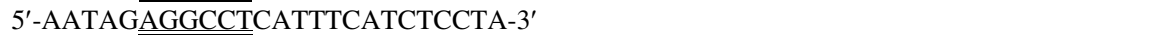 & This study \\
\hline mlr6337for & 5'-TACGTACTAGTCGCAAAAGAATCAC-3' & This study \\
\hline mlr6337rev & 5'-TTATTAGGCCTCATTGTGTCTCCTCAA-3' & This study \\
\hline
\end{tabular}

${ }^{\mathrm{a}} \mathrm{Pm}^{\mathrm{r}}, \mathrm{Sp}^{\mathrm{r}}, \mathrm{Tc}^{\mathrm{r}}, \mathrm{Ap}^{\mathrm{r}}$, and $\mathrm{Km}^{\mathrm{r}}$ indicate resistant to phosphomycin, spectinomycin, tetracycline, ampicillin, and kanamycin, respectively. ORF $=$ open reading frame; FRT = Flp recognition target. Underlines and double underlines indicate restriction sites for SpeI and StuI, respectively. 
the primer pair mlr6342U and mlr8765L (Table 3) was used to amplify the FRT-kan-FRT cassette from pKD13. Integration into cosmid 252.5 and subsequent steps for the mutant construction were carried out as described above. The mutants of type III

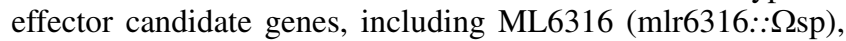

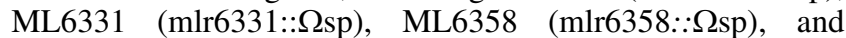

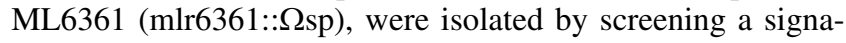
ture-tagged mutant library (Shimoda et al. 2008).

\section{Expression analysis of $t$ ts genes.}

In order to examine the expression of tts genes, we constructed $M$. loti strains carrying chromosomally integrated translational ttsI::lacZ and nopX::lacZ fusion genes (Table 3). To make the $t$ tsI::lacZ gene, the upstream 0.55 -kbp region of $t t s I$, together with its initiation codon, was amplified by PCR using primers mlr6334for and mlr6334rev (Table 3) from cosmid 251, digested with SpeI and StuI, and then cloned into the vector pSUPlacZ481uidA (S. Zehner and M. Göttfert, unpublished) that enabled fusion of the coding region of $E$. coli lac $Z$ to the ttsI initiation codon. After confirming correct construction by DNA sequencing, the plasmid was transferred to wildtype $M$. loti via biparental conjugation using E. coli $\mathrm{S} 17-1$. Because the replication origin of the vector does not function in $M$. loti, a strain with the plasmid integrated into the chromosome by single crossover recombination was selected on a TY agar plate containing tetracycline, to which the vector-encoded marker confers resistance, and phosphomycin, to which $M$. loti is naturally resistant. Following confirmation of the correct integration event by PCR, the obtained strain was designated ML033. By similar procedures using primers mlr6337for and mlr6337rev, nopX::lacZ fusion strains ML031 and ML037 were constructed with wild-type and $\Delta t t s I$ backgrounds, respectively.

In order to analyze the transcriptional regulation of $t$ ts genes under conditions known to induce nod genes, we used the heterologous nod gene induction system, comprising nodD from Rhizobium leguminosarum cloned into pMP2112 (López-Lara et al. 1995) and naringenin, because the nod gene inducer for $M$. loti has not been identified. The application of naringenin to MAFF303099 strains harboring pMP2112 is reported to induce Nod factor synthesis (Niwa et al. 2001).

Aliquots of RDM minimal medium $(20 \mathrm{ml})$ were inoculated with $200 \mu$ l of $M$. loti cultures grown for $48 \mathrm{~h}$ to stationary phase. For induction, naringenin was added to a final concentration of $1 \mu \mathrm{M}$. Uninduced cultures were treated with the corresponding amount of methanol. Cultures were grown for $48 \mathrm{~h}$ at $28^{\circ} \mathrm{C}$. $\beta$-Galactosidase activity of the cells was then determined as described previously using the 4-methylumbelliferylD-galactopyranoside as the substrate (Krause et al. 2002). Fluorescence of the reaction product 4-methylumbelliferone (MU) was measured with a fluorometer (VersaFluor Fluorometer; Bio-Rad Laboratories, Hercules, CA, U.S.A.) by excitation at $365 \mathrm{~nm}$ and by emission at $455 \mathrm{~nm}$. Galactosidase activity was calculated as pmol MU at an optical density at $600 \mathrm{~nm}$ per minute of reaction time.

\section{Purification and analysis of secreted proteins.}

M. loti strains containing pMP2112 were grown in RDM at $28^{\circ} \mathrm{C}$ for $24 \mathrm{~h}$ in the presence or absence of $1 \mu \mathrm{M}$ naringenin. Cultures were centrifuged at $5,000 \times g$ for $30 \mathrm{~min}$ and the supernatant was filtered through a membrane with a pore size of $0.45 \mu \mathrm{m}$. To precipitate proteins, ammonium sulfate $(80 \%$ final concentration) was added to the supernatants and the mixture was incubated overnight at $4^{\circ} \mathrm{C}$. Proteins were pelleted by centrifugation at $8,000 \times g$ for $45 \mathrm{~min}$ and resuspended in $50 \mathrm{mM}$ Tris- $\mathrm{HCl}(\mathrm{pH}$ 7.5). The protein suspension was mixed with trichloroacetic acid (10\% wt/vol), incubated on ice overnight, and centrifuged at $10,000 \times g$ for $30 \mathrm{~min}$ at $4{ }^{\circ} \mathrm{C}$. The protein pellet was washed with ice-cold acetone. After being dried, the pellet was resuspended in $1 \times$ SDS sample buffer $(60 \mathrm{mM}$ Tris$\mathrm{HCl}, 2 \% \mathrm{SDS}, 10 \%$ glycerol, and 5\% 2-mercaptoethanol; $\mathrm{pH}$ 6.8). Protein concentrations were determined using the BioRad protein assay kit (Bio-Rad Laboratories), and the samples were separated on SDS-PAGE (12\% wt/vol) gels and silver stained (Yan et al. 2000). To improve resolution of low molecular mass proteins, samples were loaded onto $16 \%$ TricineSDS-PAGE and prepared as described by Schägger and von Jagow (1987). For mass spectrometry analysis, bands were excised carefully from the gel and sequenced according to Fujiwara and associates (2006). The Mascot database was used to analyze mass spectrometry data (Matrix Science, London).

\section{Plant assays.}

Lotus plants used in this study were L. japonicus Gifu B129, L. filicaulis, L. halophilus (Plant Introduction [PI] accession PI 238336), L. corniculatus subsp. frondosus (accession PI 283617), L. peregrinus var. carmeli (accession PI 258396), and L. subbiflorus (accession PI 109314). Seed were provided by the Frontier Science Research Center of the University of Miyazaki, Japan, and the United States Department of Agriculture-Agricultural Research Service. For nodulation tests, seed of Lotus spp. were scarified, surface-sterilized by immersion in concentrated sulfuric acid for 3 min, rinsed 10 times with sterile water, and germinated on $0.7 \%$ (wt/vol) agar plates at $24^{\circ} \mathrm{C}$ in the dark. After 2 to 3 days, seedlings were transferred to either agar slants made with B\&D nitrogen-free medium and 0.9\% agar (Broughton and Dilworth 1971) or a plant box (CUL-JAR300; Iwaki, Tokyo, Japan) containing sterile vermiculite watered with $\mathrm{B} \& \mathrm{D}$ nitrogen-free medium. Inoculation of $M$. loti strains and plant cultivation were performed as described previously (Okazaki et al 2007).

\section{Bioinformatic and statistical analyses.}

Amino acid sequences were aligned with the CLUSTAL W algorithm following manual adjustment. The phylogenetic tree was constructed by the neighbor-joining method with the MEGA 4.0 program (Tamura et al. 2007). The evolutionary distances were computed in the units of the number of amino acid substitutions per site. All positions containing alignment gaps and missing data were eliminated only in pairwise sequence comparisons.

\section{ACKNOWLEDGMENTS}

This work was supported in part by the Special Coordination Fund for Promoting Science and Technology (to K. Saeki) and KAKENHI (Grantin-Aid for Scientific Research) on Priority Areas "Comparative Genomics" (to S. Tabata and K. Sacki) from the Ministry of Education, Culture, Sports, Science and Technology of Japan and by a Postdoctoral Fellowship for Research Abroad from the Japan Society for the Promotion of Science (to S. Okazaki). We thank the United States Department of AgricultureAgricultural Research Service and the National Bioresource Project (Lotus japonicus and Glycine max), Japan, for kindly providing Lotus spp. seed.

\section{LITERATURE CITED}

Abramovitch, R. B., Anderson, J. C., and Martin, G. B. 2006. Bacterial elicitation and evasion of plant innate immunity. Nat. Rev. Mol. Cell. Biol. 7:601-11.

Ausmees, N., Kobayashi, H., Deakin, W. J., Marie, C., Krishnan, H. B., Broughton, W. J., and Perret, X. 2004. Characterization of NopP, a type III secreted effector of Rhizobium sp. strain NGR234. J. Bacteriol. 186:4774-4780.

Bartsev, A. V., Deakin, W. J., Boukli, N. M., McAlvin, C. B., Stacey, G., Malnoë, P., Broughton, W. J., and Staehelin, C. 2004. NopL, an effector protein of Rhizobium sp. NGR234, thwarts activation of plant defense reactions. Plant Physiol. 134:871-879. 
Bellato, C., Krishnan, H. B., Cubo, T., Temprano, F., and Pueppke, S. G. 1997. The soybean cultivar specificity gene nolX is present, expressed in a $\operatorname{nod} D$-dependent manner, and of symbiotic significance in cultivarnonspecific strains of Rhizobium (Sinorhizobium) fredii. Microbiology 143:1381-1388.

Block, A., Li, G., Fu, Z. Q., and Alfano, J. R. 2008. Phytopathogen type III effector weaponry and their plant targets, Curr. Opin. Plant Biol. 11:396-403.

Broughton, W. J., and M. J. Dilworth. 1971. Control of leghaemoglobin synthesis in snake beans. Biochem. J. 125:1075-1080.

Chisholm, S. T., Coaker, G., Day, B., and Staskawicz, B. J. 2006. Hostmicrobe interactions: shaping the evolution of the plant immune response. Cell 124:803-814.

Dai, W. J., Zeng, Y., Xie, Z. P., and Staehelin, C. 2008. Symbiosis-promoting and deleterious effects of NopT, a novel type 3 effector of Rhizobium sp. strain NGR234. J. Bacteriol. 190:5101-5110.

Datsenko, K. A., and Wanner, B. L. 2000. One-step inactivation of chromosomal genes in Escherichia coli K-12 using PCR products. Proc. Natl. Acad. Sci. U.S.A. 97:6640-6645.

Deakin, W. J., Marie, C, Saad M. M., Krishnan, H. B., and Broughton, W. J. 2005. NopA is associated with cell surface appendages produced by the type III secretion system of Rhizobium sp. strain NGR234. Mol. Plant-Microbe Interact. 18:499-507.

de Lyra, M. d. C., Lopez-Baena, F. J., Madinabeitia, N., Vinardell, J. M., Espuny, M. R., Cubo M. T., Belloguin, R. A., Ruiz-Sainz, J. E., and Ollero, F. J. 2006. Inactivation of the Sinorhizobium fredii HH103 rhcJ gene abolishes nodulation outer proteins (Nops) secretion and decreases the symbiotic capacity with soybean. Int. Microbiol. 9:125133.

Dixon, R. A., and Paiva, N. L. 1995. Stress-induced phenylpropanoid metabolism. Plant Cell 7:1085-1097.

Dixon, R. A., and Steele, C. L. 1999. Flavonoids and isoflavonoids-a gold mine for metabolic engineering. Trends Plant Sci. 4:394-400.

Evdokimov, A. G., Anderson, D. E., Routzahn, K. M., and Waugh, D. S. 2001. Unusual molecular architecture of the Yersinia pestis cytotoxin YopM: a leucine-rich repeat protein with the shortest repeating unit. J. Mol. Biol. 312:807-821.

Freiberg, C., Fellay, R., Bairoch, A., Broughton, W. J., Rosenthal, A., and Perret, X. 1997. Molecular basis of symbiosis between Rhizobium and legumes. Nature 387:394-401.

Fujiwara, M., Umemura, K., Kawasaki, T., and Shimamoto, K. 2006. Proteomics of Rac GTPase signaling reveals its predominant role in elicitor-induced defense response of cultured rice cells. Plant Physiol. 140:734-745

Galibert, F., Finan, T. M,. Long, S. R., Puhler, A., Abola, P., Ampe, F., Barloy-Hubler, F., Barnett, M. J., Becker, A., Boistard, P., Bothe, G. Boutry, M., Bowser, L., Buhrmester, J., Cadieu, E., Capela, D., Chain, P., Cowie, A., Davis, R. W., Dreano, S., Federspiel, N. A., Fisher, R. F. Gloux, S., Godrie, T., Goffeau, A., Golding, B., Gouzy, J., Gurjal, M., Hernandez-Lucas, I., Hong, A., Huizar, L., Hyman, R. W., Jones, T., Kahn, D., Kahn, M. L., Kalman, S., Keating, D. H., Kiss, E., Komp, C., Lelaure, V., Masuy, D., Palm, C., Peck, M. C., Pohl, T. M., Portetelle, D., Purnelle, B., Ramsperger, U., Surzycki, R., Thebault, P., Vandenbol, M., Vorholter, F. J., Weidner, S., Wells, D. H., Wong, K., Yeh, K. C., and Batut, J. 2001. The composite genome of the legume symbiont Sinorhizobium meliloti. Science 293:668-672.

Gan, J., Gu, Y., Li, Y., Yan, H., and Ji, X. 2006. Crystal structure of Mycobacterium tuberculosis shikimate kinase in complex with shikimic acid and an ATP analogue. Biochemistry 45:8539-8545.

Görlach, J., Raesecke, H. R., Rentsch, D., Regenass, M., Roy, P., Zala, M. Keel, C., Boller, T., Amrhein, N., and Schmid, J. 1995. Temporally distinct accumulation of transcripts encoding enzymes of the prechorismate pathway in elicitor-treated, cultured tomato cells. Proc. Natl. Acad. Sci. U.S.A. 92:3166-3170.

Grant, S. R., Fisher, E. J., Chang, J. H., Mole, B. M., and Dangl, J. L. 2006. Subterfuge and manipulation: Type III effector proteins of phytopathogenic bacteria. Annu. Rev. Microbiol. 60:425-449.

Gu, Y., Reshetnikova, L., Li, Y., Wu, Y., Yan, H., Singh, S., and Ji, X. 2002. Crystal structure of shikimate kinase from Mycobacterium tuberculosis reveals the dynamic role of the LID domain in catalysis. J. Mol. Biol. 319:779-789.

Guttman, D. S., Vinatzer, B. A., Sarkar, S. F., Ranall, M. V., Kettler, G., and Greenberg, J. T. 2002. A functional screen for the type III (Hrp) secretome of the plant pathogen Pseudomonas syringae. Science 295:1722-1726.

Haraga, A., and Miller, S. I. 2003. A Salmonella enterica serovar typhimurium translocated leucine-rich repeat effector protein inhibits NFkB-dependent gene expression. Infect. Immun. 71:4052-4058.

Hartmann, M. D., Bourenkov, G. P., Oberschall, A., Strizhov, N., and Bartunik H. D. 2006. Mechanism of phosphoryl transfer catalyzed by shikimate kinase from Mycobacterium tuberculosis. J. Mol. Biol. 364:411-423

Hattori, Y., Omori, H., Hanyu, M., Kaseda, N., Mishima, E., Kaneko, T., Tabata, S., and Saeki, K. 2002. Ordered cosmid library of the Mesorhizobium loti MAFF303099 genome for systematic gene disruption and complementation analysis. Plant Cell Physiol. 43:1542-1557.

Herrmann, K. M. 1995. The shikimate pathway: early steps in the biosynthesis of aromatic compounds. Plant Cell 7:907-919.

Hubber, A., Vergunst, A. C., Sullivan, J. T., Hooykaas, P. J., and Ronson, C. W. 2004. Symbiotic phenotypes and translocated effector proteins of the Mesorhizobium loti strain R7A VirB/D4 type IV secretion system. Mol. Microbiol. 54:561-574.

Jones, J. D. G., and Dangl, J. L. 2006. The plant immune system. Nature 444:323-329

Kambara, K., Ardissone, S., Kobayashi, H., Saad, M. M., Schumpp, O. Broughton, W. J., and Deakin, W. J. 2009. Rhizobia utilize pathogenlike effector proteins during symbiosis. Mol. Microbiol. 71:92-106.

Kaneko, T., Nakamura, Y., Sato, S., Asamizu, E., Kato, T., Sasamoto, S. Watanabe, A., Idesawa, K., Ishikawa, A., Kawashima, K., Kimura, T., Kishida, Y., Kiyokawa, C., Kohara, M., Matsumoto, M., Matsuno, A., Mochizuki, Y., Nakayama, S., Nakazaki, N., Shimpo, S., Sugimoto, M. Takeuchi, C., Yamada, M., and Tabata, S. 2000. Complete genome structure of the nitrogen-fixing symbiotic bacterium Mesorhizobium loti. DNA Res. 7:331-338.

Kasai, K., Kanno, T., Akita, M., Ikejiri-Kanno, Y., Wakasa, K., and Tozawa Y. 2005. Identification of three shikimate kinase genes in rice: characterization of their differential expression during panicle development and of the enzymatic activities of the encoded proteins. Planta 222:438 447.

Kobe, B., and Kajava, A. V. 2001. The leucine-rich repeat as a protein recognition motif. Curr. Opin. Struct. Biol. 11:725-732.

Krause, A., Doerfel, A., and Göttfert, M. 2002. Mutational and transcriptional analysis of the type III secretion system of Bradyrhizobium japonicum. Mol. Plant-Microbe Interact. 15:1228-1235.

Krell, T., Coggins, J. R., and Lapthorn, A. J. 1998. The three-dimensional structure of shikimate kinase. J. Mol. Biol. 278:983-997.

Krishnan, H. B. 2002. NolX of Sinorhizobium fredii USDA257, a type IIIsecreted protein involved in host range determination, is localized in the infection threads of cowpea (Vigna unguiculata (L.) Walp) and soybean (Glycine max [L.] Merr.) nodules. J. Bacteriol. 184:831-839.

Krishnan, H. B., Lorio, J., Kim, W. S., Jiang, G., Kim, K. Y., DeBoer, M., and Pueppke, S. G. 2003. Extracellular proteins involved in soybean cultivar-specific nodulation are associated with pilus-like surface appendages and exported by a type III protein secretion system in Sinorhizobium fredii USDA257. Mol. Plant-Microbe Interact. 16:617-625.

López-Lara, I. M., van den Berg, J. D., Thomas-Oates, J. E., Glushka, J., Lugtenberg, B. J., and Spaink, H. P. 1995. Structural identification of the lipo-chitin oligosaccharide nodulation signals of Rhizobium loti. Mol. Microbiol. 15:627-638.

Marie, C., Broughton, W. J., and Deakin, W. J. 2001. Rhizobium type III secretion systems: legume charmers or alarmers? Curr. Opin. Plant Biol. 4:336-342.

Marie, C., Deakin, W. J., Viprey, V., Kopciñska, J., Golinowski, W., Krishnan, H. B., Perret, X., and Broughton, W. J. 2003. Characterization of Nops, nodulation outer proteins, secreted via the type III secretion system of NGR234. Mol. Plant-Microbe Interact. 16:743-751.

Marie, C., Deakin, W. J., Ojanen-Reuhs, T., Diallo, E., Reuhs, B., Broughton, W. J., and Perret, X. 2004. TtsI, a key regulator of Rhizobium species NGR234 is required for type III-dependent protein secretion and synthesis of rhamnose-rich polysaccharides. Mol. Plant-Microbe Interact. 17:958-966.

Meinhardt, L. W., Krishnan, H. B., Balatti, P. A., and Pueppke, S. G. 1993. Molecular cloning and characterization of a sym plasmid locus that regulates cultivar-specific nodulation of soybean by Rhizobium fredii USDA257. Mol. Microbiol. 9:17-29.

Niwa, S., Kawaguchi, M., Imazumi-Anraku, H., Chechetka, S. A., Ishizaka, M., Ikuta, A., and Kouchi, H. 2001. Responses of a model legume Lotus japonicus to lipochitin oligosaccharide nodulation factors purified from Mesorhizobium loti JRL501. Mol. Plant-Microbe Interact. 14:848-856

Okazaki, S., Hattori, Y., and Saeki, K. 2007. The Mesorhizobium loti purB gene is involved in infection thread formation and nodule development in Lotus japonicus. J. Bacteriol. 189:8347-8352.

Petnicki-Ocwieja, T., Schneider, D. J., Tam, V. C., Chancey, S. T., Shan, L., Jamir, Y., Schechter, L. M., Janes, M. D., Buell, C. R., Tang, X., Collmer, A., and Alfano, J. R. 2002. Genomewide identification of proteins secreted by the Hrp type III protein secretion system of Pseudomonas syringae pv. tomato DC3000. Proc. Natl. Acad. Sci. U.S.A. 99:7652-7657.

Ronson, C. W., Nixon, B. T., Albright, L. M., and Ausubel, F. M. 1987. 
Rhizobium meliloti ntrA (rpoN) gene is required for diverse metabolic functions. J. Bacteriol. 169:2424-2431.

Saad, M. M., Kobayashi, H., Marie, C., Brown, I. R., Mansfield, J. W., Broughton, W. J., and Deakin, W. J. 2005. NopB, a type III secreted protein of Rhizobium sp. strain NGR234, is associated with pilus-like surface appendages. J. Bacteriol. 187:1173-1181.

Saad, M. M., Staehelin, C., Broughton, W. J., and Deakin, W. J. 2007. Protein-protein interactions within type III secretion system-dependent pili of Rhizobium sp. strain NGR234. J. Bacteriol. 190:750-754.

Saeki, K., and Kouchi, H. 2000. The Lotus symbiont, Mesorhizobium loti: molecular genetic techniques and application. J. Plant. Res. 113:457465 .

Sambrook, J., and Russel, D. W. 2001. Molecular Cloning: A Laboratory Manual, 3rd ed. Cold Spring Harbor Laboratory Press, Cold Spring Harbor, NY, U.S.A.

Schägger, H., and von Jagow, G. 1987. Tricine-sodium dodecyl sulfatepolyacrylamide gel electrophoresis for the separation of proteins in the range from 1 to $100 \mathrm{kDa}$. Anal. Biochem. 166:368-379.

Schlumberger, M. C., and Hardt, W. D. 2006. Salmonella type III secretion effectors: pulling the host cell's strings. Curr. Opin. Microbiol. 9:46-54.

Shimoda, Y., Mitsui, H., Kamimatsuse, H, Minamisawa, K., Nishiyama, E., Ohtsubo, Y., Nagata, Y., Tsuda, M., Shinpo, S., Watanabe, A., Kohara, M., Yamada, M., Nakamura, Y., Tabata, S., and Sato, S. 2008. Construction of signature-tagged mutant library in Mesorhizobium loti as a powerful tool for functional genomics. DNA Res. 15:297-308.

Simon, R., Priefer, U., and Pühler, A. 1983. A broad host range mobilization system for in vivo genetic engineering: transposon mutagenesis in gram negative bacteria. Bio/technology 1:784-791.

Skorpil, P., Saad, M. M., Boukli, N. M., Kobayashi, H., Ares-Orpel, F., Broughton, W. J., and Deakin, W. J. 2005. NopP, a phosphorylated effector of Rhizobium sp. strain NGR234, is a major determinant of nodulation of the tropical legumes Flemingia congesta and Tephrosia vogelii. Mol. Microbiol. 57:1304-1317.

Sullivan, J. T., Trzebiatowski, J. R., Cruickshank, R. W., Gouzy, J., Brown, S. D., Elliot, R. M., Fleetwood, D. J., McCallum, N. G., Rossbach, U., Stuart, G. S., Weaver, J. E., Webby, R. J., De Bruijn, F. J., and Ronson C. W. 2002. Comparative sequence analysis of the symbiosis island of Mesorhizobium loti strain R7A. J. Bacteriol. 184:3086-3095.

Süss, C., Hempel, J., Zehner, S., Krause, A., Patschkowski, T., and Göttfert, M. 2006. Identification of genistein-inducible and type III-secreted proteins of Bradyrhizobium japonicum. J. Biotechnol. 126:69-77.

Tamura, K., Dudley, J., Nei, M., and Kumar, S. 2007. MEGA4: Molecular evolutionary genetics analysis (MEGA) software version 4.0. Mol. Biol. Evol. 24:1596-1599.

Viprey, V., Del Greco, A., Golinowski, W., Broughton, W. J., and Perret, X. 1998. Symbiotic implications of type III protein secretion machinery in Rhizobium. Mol. Microbiol. 28:1381-1389.

Walker, J. E., Saraste, M., Runswick, M. J., and Gay, N. J. 1982. Distantly related sequences in the alpha- and beta-subunits of ATP synthase, myosin, kinases and other ATP-requiring enzymes and a common nucleotide binding fold. EMBO (Eur. Mol. Biol. Organ.) J. 1:945-951.

Wassem, R., Kobayashi, H., Kambara, K., Le, Q. A., Walker, G. C., Broughton, W. J., and Deakin, W. J. 2008. TtsI regulates symbiotic genes in Rhizobium species NGR234 by binding to tts boxes. Mol. Microbiol. 68:736-748.

Yan, J. X., Wait, R., Berkelman, T., Harry, R. A., Westbrook, J. A., Wheeler, C. H., and Dunn, M. J. 2000. A modified silver staining protocol for visualization of proteins compatible with matrix-assisted laser desorption/ionization and electrospray ionization-mass spectrometry. Electrophoresis 21:3666-3672.

Young, J. P., Crossman, L. C., Johnston, A. W., Thomson, N. R., Ghazoui, Z. F., Hull, K. H., Wexler, M., Curson, A. R., Todd, J. D., Poole, P. S., Mauchline, T.H., East, A. K., Quail, M. A., Churcher, C., Arrowsmith, C., Cherevach, I., Chillingworth, T., Clarke, K., Cronin, A., Davis, P., Fraser, A., Hance, Z., Hauser, H., Jagels, K., Moule, S., Mungall, K., Norbertczak, H., Rabbinowitsch, E., Sanders, M., Simmonds, M., Whitehead, S., and Parkhill, J. 2006. The genome of Rhizobium leguminosarum has recognizable core and accessory components. Genome Biol. 7:R34.

Zehner, S., Schober, G., Wenzel, M., Lang, K., and Göttfert, M. 2008. Expression of the Bradyrhizobium japonicum type III secretion system in legume nodules and analysis of the associated tts box promoter. Mol. Plant-Microbe Interact. 21:1087-1093.

Zhou, J. M., and Chai, J. 2008. Plant pathogenic bacterial type III effectors subdue host responses. Curr. Opin. Microbiol. 11:179-185.

Zhu, Y., Li, H., Hu, L., Wang, J., Zhou, Y., Pang, Z., Liu, L., and Shao, F. 2008. Structure of a Shigella effector reveals a new class of ubiquitin ligases. Nat. Struct. Mol. Biol. 15:1302-1308.

\section{AUTHOR-RECOMMENDED INTERNET RESOURCES}

National Center for Biotechnology Information Conserved domain database: www.ncbi.nlm.nih.gov/Structure/cdd/cdd.shtml

RhizoBase: genome.kazusa.or.jp/rhizobase 